\title{
David Oliver: What GPs told me about how they see the future
}

\section{David Oliver consultant in geriatrics and acute general medicine}

Berkshire

In June I wrote a column that was very supportive of primary care but asked, in view of serious current problems and an uncertain future, for a consensus from GPs themselves on the future of primary care. ${ }^{1}$ An excellent collection of rapid responses helped me (and hopefully other non-GPs) to understand the current mood. ${ }^{2}$

One point of consensus seemed clear: there simply is no consensus about future models of general practice, and we shouldn't expect one. General practices and the communities they serve are just too diverse, and different doctors want different things from their careers. That's OK. Most respondents found delivery and employment models secondary considerations. Some were happy to work as salaried GPs in networks or integrated care providers and for others to take on partnership.

There were points of general agreement: firstly, that the most pressing crises were the chronic underfunding of general practice, which has fallen as a percentage of NHS spending even as activity has risen, ${ }^{3}$ and major workforce gaps. An editorial in The BMJ in July suggested that we are underestimating the workforce gap ${ }^{4}$ - and that it isn't likely to be tackled either by recruiting GPs trained overseas or by the GP Forward View, ${ }^{5}$ which is not on track to provide all of the full time equivalent GPs it planned or to plug the hole left by retirees. ${ }^{6}$

In a hierarchy of needs, general practice's very survival was what mattered most. The constant undermining narrative that general practice is unsustainable or not fit for purpose-and that it should be subsumed into scaled up collaborative models of primary care beyond the traditional group practice or bigger locality health systems - was seen as partly driven by politics and as a threat to general practice as we know it. Some respondents did argue, however, that modernisation is needed to deliver more care for increasingly complex patients at scale outside hospital.

Secondly, "one size fits all" models of big general practice are seen as pointless in rural and remote communities, where distances are bigger and where the skilled expert generalist, confident in subacute care, is at a premium.

Thirdly, patients still greatly value the continuity and personal approach of traditional general practice, although they might trade some of this for rapid access. Several respondents argued that traditional, small group practice models are still best able to provide this cost effectively and that GPs are best placed to support people with diagnostic uncertainty, multiple morbidity, and undifferentiated symptoms.

Patients greatly value the continuity and personal approach of traditional general practice, although they might trade some of this for rapid access

To my mind, a problematic dissonance still exists in the push from some leading GPs to devolve increasing amounts of care to the community and out of hospitals, when primary care is already overwhelmed and underfunded. I also perceive a mismatch between the values of younger doctors, often wanting less than full time or fully clinical roles ${ }^{7}$ (often salaried), and those still promoting the partnership model.

This is perhaps why the most interesting responses to me were from the GP and academic Richard Byng (especially insightful: www.bmj.com/content/357/bmj.j2949/rr-12) and from the GPs Jonathon Tomlinson (www.bmj.com/content/357/bmj.j2949/rr4) and Martin Marshall (www.bmj.com/content/357/bmj.j2949/ rr-11). In their own way, all raised the meta-questions of what general practice is really for, how its approach differs from the rest of medicine, and what parts of it require the skills of a doctor, as opposed to other staff groups or self care. But I saw surprisingly little discussion of the serious workforce gaps in district nursing or community health and social care services, which surely hamper good general practice.

With the population's health needs changing so drastically, it's surely vital to reflect on what general practice is and isn't for, and what it should and shouldn't do, as Margaret McCartney set out in a recent $B M J$ column. ${ }^{8}$ 
Competing interests: See www.bmj.com/about-bmj/freelancecontributors/david-oliver.

Provenance and peer review: Commissioned; not externally peer reviewed.

Follow David on Twitter: @mancunianmedic

Oliver D. David Oliver: Towards a GP consensus on the future of UK general practice. BMJ 2017;358:j2949. doi:10.1136/bmj.j2949 pmid:28634249.

2 Rapid responses: Towards a GP consensus on the future of UK general practice. www. bmj.com/content/357/bmj.j2949/rapid-responses.

3 King's Fund. Understanding pressures in general practice. May 2016. https://www. kingsfund.org.uk/sites/files/kf/field/field_publication_file/Understanding-GP-pressuresKings-Fund-May-2016.pdf.
4 Majeed A. Shortage of general practitioners in the NHS. BMJ 2017;358:j3191. doi:10. 1136/bmj.j3191 pmid:28694250

5 Royal College of General Practitioners. General practice forward view-what does it mean? 2016. www.rcgp.org.uk/-/media/Files/Policy/General-Practice-Forward-View/RCGPGeneral-Practice-Forward-View-what-does-it-mean-2016.ashx?la=en.

6 Campbell D. NHS to spend $£ 100 \mathrm{~m}$ bringing in up to $3000 \mathrm{GPs}$ from abroad. Guardian 31 Aug 2017. https://www.theguardian.com/society/2017/aug/31/nhs-spend-100m-bringingin-3000-gps-abroad-england.

7 Gulland A. Are millennial GPs shunning full time working?BMJ 2017;358:j3059.pmid: 28655720.

8 McCartney M. Margaret McCartney: Let's ditch the stuff we don't need to do. BMJ 2017;358:j3457. doi:10.1136/bmj.j3457 pmid:28720573.

Published by the BMJ Publishing Group Limited. For permission to use (where not already granted under a licence) please go to http://group.bmj.com/group/rights-licensing/ permissions 